\title{
Militainment in British Cinema: Analysis Based on Selected Film Productions
}

\author{
Olga Bogdańska
}

\begin{abstract}
Since the invention of cinematography, scenes of battles have fascinated directors and have become an important element of film art. Over the years, the British film industry has developed a rich repertoire of conventions to present warfare. Moreover, the military history of this country is regarded as an inexhaustible source of inspiration which can be converted into a countless number of screenplays. In recent years, it has been argued that a transformation in the paradigm of presenting war in comparison with the times of the Great World Wars has appeared. The phenomenon is called militainment. To propose a precise definition of this term proves to be problematic. It is commonly used to describe the presentation of military elements in popular culture and the ways in which contemporary media depict war drama as a fascinating and entertaining spectacle. It seems crucial to describe factors which may have led to the appearance and development of militainment in the context of film studies. Consequently, the aim of this paper is to provide a forum for discussing how militainment has influenced the presentation of war in films that were produced in the United Kingdom.
\end{abstract}

Index Terms-British cinema, militainment, popular culture, war films.

\section{INTRODUCTION: WhAT IS MiLITAINMENT}

Militainment appeared in Western culture after the attacks on the World Trade Center on September $11^{\text {th }}, 2001$, and its consequences have contributed to changes in popular culture mainly in the United States and Western European countries. The definition of militainment is complex to characterize, although the general concept is based on the translation of its name, which comes from two English words, militarism and entertainment. It is associated with the presence of military elements in popular culture, and it is used to describe the ways in which contemporary media depict war drama as a fascinating and entertaining spectacle. However, it is difficult to identify the exact moment in which the word for the phenomenon was adopted into the English language, but we can identify a few situations in which it was used. The term can be found in James Poniewozik's article: "That's Militainment" which was published March 4, 2002, in the magazine Time. Five years later the documentary film Militainment Inc. appeared in the United States, which was an attempt to answer the question of how war had become a spectacle of entertainment. The author of the film, Roger Stahl, noted that "we gather to watch the war in the same way that we might gather to watch the Oscars or a large sporting

Manuscript received August 24, 2013; revised October 25, 2013

O. Bogdańska is with the Interdisciplinary Doctoral Program in the Humanities within the Faculty of Philosophy and History, University of Lodz, Poland (e-mail: olgabogdanska@ gmail.com). event" [1]. This suggests that the topic of war stops being presented only in terms of information, but becomes a form of entertainment.

It is crucial to describe the factors that have contributed to the appearance and development of the phenomenon in general. Scholars connect this interest in the subject of war with the social fascination with violence. In antiquity people were excited by bloody pleasure, such as gladiator fights in amphitheatres. During the Middle Ages crowds gathered to witness the spectacles of jousting tournaments and the burning of witches at the stake [2]. Today the need for extreme sensations that occupied the ancients has not disappeared. But with the development of mass media, the way to satisfy this need has changed. Nowadays we can gain contact with brutality in the cinema, celebrating violence through the film experience. This human need to have contact with cruelty is explained in several ways. It is believed that it serves to offset angor animi, or the fear of death [3]. Also, through the frequent portrayal of death, the public gets used to its presence. In addition, entertainment has become an escape from the everyday boredom of life, and cinema can guarantee strong sensations.

Modern war presentation is also influenced by popular culture. The term 'popular culture' is used in relation to culture which is commercially produced and which is addressed to a mass audience focused on pleasure [4]. The desire to derive pleasure from every conceivable area of life has been described by Mikhail Bakhtin as carnivalisation [5]. Its manifestation can be found in the mass media, especially in the cinema, which was designed to give people entertainment.

The discussion of the roots of militainmnet should also take into account political and ideological factors. Culture in fact operates in a specific social space, which can change in time. Treating war as a form of entertainment should be considered with political and ideological issues. A change in public attitudes towards war takes place at the level of ideology which includes the set of ideas reflecting the social needs and aspirations of an individual group [4]. In addition, ideology is perceived as a kind of a tool for controlling other groups. Culture is the main area of the presentation of political views and the place where groups can fight for hegemony [6]. So when the war in Iraq started, largely as a consequence of the World Trade Center bombings, the ruling elite had to convince the public that this action was right Therefore, a new positive image of war was created for political purposes. Then the mass media, including the cinema, started to present war as a patriotic duty. This helped society to accept the reality of war.

Technological development has been another factor that 
increased the popularity of the phenomenon. Although the name militainment was coined in the early twenty-first century, the phenomenon is not new. Since December 1895, when the Lumieres conducted the first public screening of a film, filmmakers were interested in war scenes. The first commercial film about war was directed by British director James Williamson, a member of the "Brighton school". Attack on a China Mission had its premiere on November 17, 1900, in the Hove Town Hall. The storyline refers to the Boxer Rebellion in China between 1898 and 1901. The four-minute production presents the story of a missionary who was killed by members of a secret society. At the end of the premiere, the audience was so impressed that it demanded an encore of the screening [7]. Already with the first screening of a war film, it gained the status of an attractive spectacle. With the end of the twentieth century, cinema has become the most perfect medium for presenting war.

Another significant factor in the occurrence of militainment in British war films comes from outside the UK: Hollywood. Throughout their history, British films have played an important social role. After the end of World War II, the British film industry, with its directors, producers, and actors, was supposed to compete effectively with global cinema, including American productions. Unfortunately, a lack of interest in the film industry by a conservative government led to the economic decline of the industry. Due to financial problems, war films started to be jointly produced by both US and UK studios, made possible by the strong cultural and linguistic ties Britain has had with the USA. The most famous co-productions include: A Bridge Too Far, Where Eagles Dare, The Dirty Dozen, and Full Metal Jacket. In this way, new models of presenting war on the big screen started arriving in Great Britain from overseas. This process is identified as the Hollywoodisation of British cinema [8].

\section{WAR THROUGH CAMERA LENS}

In British culture we can find a variety of ways to present scenes of war. This theme is universal and can take thousands of forms: a propaganda tool, a message of patriotism, an objective presentation of events, or entertainment. Over the years, in order to attract viewers' attention, filmmakers have developed an innovative approach towards the subject: comedy.

\section{A. Make Laugh Not War}

British filmmakers came up with the idea of presenting war in a comic way. The "fun factor" is regarded as the most characteristic criterion of militainment. As was mentioned previously, one of the words forming the name of the phenomenon is 'entertainment'. It is defined as "something that is designed to bring pleasure" [9]. Jokes, funny gags, and sarcasm are used in films to evoke joy and happiness. The British people are known round the world for their sophisticated senses of humor. French director Jacques Doniol-Valcroze described it as: "Humor pink or grim, always phlegmatic, sometimes gruesome" [10]. Monty Python, the most popular comedy group from the UK, is an example of British humor at its best. It was founded in the late sixties by six men: Graham Chapman, John Cleese, Terry
Gilliam, Eric Idle, Terry Jones and Michael Palin. Their creativity is based on absurdity, provocation, surreal humor, and a nonchalant attitude towards serious matters.

In 1983 the Pythons produced a feature-length film, Monty Python's The Meaning of Life, which presented a black humor vision of war. This nearly two-hour film is divided into seven parts. For this paper the most crucial is the third one titled "Fighting Each Other". It consists of a few sketches presenting nonsensical situations from the battlefield. One of them takes place at the front during the First World War, where a commander is celebrating his birthday with cake and presents. Another shows a group of soldiers marching up and down the square. There follows a sketch about the Zulu War in the nineteenth century. When soldiers are fighting with Zulus, next to them officers of Her Majesty calmly shave themselves and drink whiskey. Then they try to solve a mysterious puzzle: during the night one of the officers had his leg bitten off by a tiger. The irony used by the comedians allows the audience to react with laughter at battle scenes and maintain a proper distance from the presented events [11].

Filmmakers also play with the time and place of events. In Monty Python's Meaning of Life two conflicts were chosen: the Zulu War from 1848 and World War I. But in the film the chronology has been disrupted. The sketch about World War I, which began in the summer of 1914, starts the sequence, and then it is followed by the presentation of the war from the nineteenth century. Furthermore, the location may influence the reception of the story. Militainment includes the use of landscape aesthetics, which simplifies the setting in order to achieve the effect of unreality in the screen world. In the case of Monty Python, the absolute lack of attention to details about the setting is observed. The Zulu War scenes were filmed in the United Kingdom and the viewer is directly informed about that fact. On the screen appears the notification: 1st Zulu War (Glasgow). Such planned manipulations make a clear distinction between reality and fiction and allow for the acceptance of war.

In order to analyze the quintessence of British comedy, it is important to focus on dialogue. For example, in the first sketch when soldiers hand over a greeting card, they apologize that it is dirty because of the blood. Statements comparing war to fun also appear. For example a wounded soldier in the fight with Zulus says: "Bloody good fun, sir, is it not?" The comedians leach war of all its recognized values and satirize the British army: Narrator: "Democracy and humanitarianism have always been trademarks of the British Army/Sergeant Major: Rubbish!" In addition, the dialogue includes vulgar and politically incorrect wording, which serves to reduce tension: "Better than staying at home, isn't this sir? I mean, at home if you kill someone, they arrest you. Here, they give you a gun and show you what to do sir. I mean I killed fifteen of those buggers, sir. Now, at home, they'd hang me! Here, they'll give me fucking medal, sir!" These expressions ridicule and diminish the idea of war in the eyes of the audience, making it easier to accept.

Monty Python's The Meaning of Life is presented as an example of militainment despite the fact that it was directed in the 1980's when this notion had not yet been formulated. However, it is worth discussing because it is perceived as an excellent example of this phenomenon in the United 
Kingdom. It illustrates the British unique sense of humor based on the idea of treating serious themes with a pinch of salt. These six eccentric men presented the serious issue as war in a completely grotesque way. Their innovative approach gained worldwide popularity, which can be proved by its awarding of the Golden Palm at the Cannes Film Festival and an Oscar for the script. Since then, British filmmakers have often used jokes about violence and death, and war has become an interesting subject of numerous parodies, as in the 2004 comedy Churchill: The Hollywood Years. Militainment appears as a consequence of presenting the tragedies of battle with elements of humor to fascinate and entertain cinematic audiences.

\section{B. War and Beauty}

The Second World War still fascinates cinema, but recently there have been numerous attempts to look back at that war. Therefore, filmmakers are looking for innovative solutions to show it from a different perspective. Consequently, the war has often stopped being a guiding theme and has become only a background which influences the particular heroes or events. This has stimulated new cinematic interest in war films which tend to concentrate on war-time romances. This motif has been used, inter alia, in productions such as The English Patient, Pearl Harbor and A Very Long Engagement. This trend is reproduced by British director Joe Wright in his The Atonement (2007) based on the novel by Ian McEwan.

The film describes the relationship between the son of a housekeeper, Robbie Turner, and a girl from a wealthy family, Cecilia Tallis. The situation becomes complicated when their passion is badly interpreted by 13 -year-old Briony Tallis, Cecilia's sister. This young girl, with an artistic soul and vivid imagination, falsely accuses Robbie of a crime he did not commit. He is arrested and five years later is sent to the war front in France. War, presented in the context of the romance of the main characters, has a symbolic meaning. It is defined as the obstacle to the realization of desires. In all cinematographies in the world "war" and "love" appear close together.

Along with the development of love stories in war films, erotic images also started to be displayed. This was possible thanks to the sexual liberalization in European cinematography, strongly influenced by Hollywood films and the development of popular culture. In Great Britain it followed the end of the First World War, after the sexual revolution which undermined the basis of Victorian morality [12]. The presence of sex scenes and sexual themes brought a new dimension to war movies. They started to be more entertaining because of the ability to excite viewers and give them vicarious pleasure [13].

In The Atonement, eroticism was very clearly emphasized. The beginning of the film especially focuses on the scenes of seduction between Cecilia and Robbie. It is based on both a mutual attraction and repulsion between the partners. Finally, there even occurs a scene of the sexual act. Apart from that, the linguistic side of this initial sequence plays an important role in shaping the erotic atmosphere of the film. For example, Robbie writes a letter to his beloved with obscene sentences such as, "In my dreams I kiss your sweet wet c u n t". The action takes place during an extremely hot day of summer, so in the dialogue we can find expressions like "hot weather encouraged loose morals" or "does the hot weather make you behave badly?" Another manifestation of eroticism is the fetishism of the female body on the screen. In the case of The Atonement, the main character is played by Keira Knightley. Her feminine sexuality is exposed in a scene in the garden, when, in her underwear, she jumps into a fountain for a piece of broken vase and the wet material clings to her body.

Surprisingly, current trends in war films include a development toward fewer battle scenes in favor of observations of the heroes' emotions. This is exactly what we can observe in The Atonement where there's an absolute lack of battle scenes. Accordingly, on-screen war is greatly simplified by filmmakers who prefer to capture only the "essence" of war events and show distant massive destruction, burning buildings, or cannon shots heard in the background. The "evacuation of Dunkirk" scene in The Atonement may well prove this idea. This one-take Steadicam shot appears in the middle of the film and tells the story of Robbie who is trying to return to England from the beaches of Dunkirk. The camera follows him moving around the beach. In the background we have a flow of images of wounded soldiers and cavalry horses being shot, accompanied by a singing choir. But the aim of this representation is not to illustrate the historical events from "Operation Dynamo" during the Dunkirk evacuation in 1940, but to focus on the emotions, feelings and pain of the main character who is missing his love.

Militainment also includes what can be generally understood as beauty. Filmmakers look for ways to present war as a subtle, unrealistic, and even beautiful spectacle. The process of transforming something awful into something nice is called "aesthetics" [14]. There are a multitude of the definitions of this concept. Mike Featherstone proposed three meanings of the term. The first one is the "blurring the boundary between art and everyday life", the other means the "transformation of life into a work of art", and the last is "a flood of signs and symbols in the structure of everyday life in modern society" [15]. In relation to militainment, Wolfgang Welsch makes a very interesting observation. According to him, the aesthetics of reality are based on its virtualization. Film and television do not represent reality, but merely create the illusion of the outside world. This concept was described in 1981 by Jean Baudrillard and defined as the simulacrum. The confirmation of this thesis is presented in an essay by the sociologist Kazimierz Krzysztofka, titled "Mixed Culture." He presents a story of an American woman who was a witness of the terrorist attack on the WTC in 2001. Interestingly, she preferred to watch the situation on television than observe it directly from the windows of her apartment [16]. It is the same with cinema that allows the viewer to see the events that actually cause fear and disgust from a safe and comfortable cinema seat. Thus the media increase the distance between the viewer and the object. This lack of realism is described as the barrier of the silver screen.

But the question is what mechanics should be used to change war into something beautiful? To find the answer it can be helpful to examine the concept of the "society of the spectacle" created by French writer and philosopher Guy 
Debord. His main idea implies that: "in societies where modern conditions of production prevail, all of life presents itself as an immense accumulation of spectacles. Everything was directly lived has moved away into a representation" [17]. War films for a long time have been a fertile field for spectacle, but now this situation is changing. It seems now that more glamour and attention-grabbing are called for. First of all, filmmakers started to be more concerned about the soundtrack, and over the next years even special songs were recorded for a particular movie. This was discussed by many researches who coined the theory of videoclip aesthetics [18]. It refers to the situation when scenes from the film are strongly integrated with a musical motif [19]. For instance in The Atonement, music masterfully portrays the atmosphere of situations, as when the emotional and melodic track "Elegy for Dunkirk" reinforces the drama of the previously described scene of the evacuation of Dunkrik. It was composed by Italian musician Dario Marianelli and performed by the English Chamber Orchestra. Critics have pointed out that a viewer can feel a strong correlation between the events on the screen and this soundtrack. Music in war films can focus on pleasure and provide the viewer with a strong aesthetic experience.

Additionally, the effect of spectacle is also achieved by the selection of appropriate sets and scenery. In The Atonement the set was built on the basis of contrast to distinguish the time before and during the war. For the first segment, a Victorian manse was used as the main setting. The dominance of pastel colors is noticeable. Ivory, pink, and beige are frequently seen. Decorations are mainly rich with floral motifs. It disappears in part two when the action is moved to the front lines of World War II. Scenery is significantly changed and sepia style sweeps prevail. Stereotypical visual effects are used such as fire, dust, smoke. War once again is reduced to a few symbols. Therefore, thanks to this kind of modifications, the effect of reality vanishes.

\section{War: Fiction and Reality}

Currently, movies about recent armed conflicts, i.e. the Iraq invasion of 2003, have appeared on the big screen. A recent British example is Battle for Haditha, directed by Nick Broomfield in 2007. It is based on the series of events which led to the tragedy of November 19, 2005, in the small town of Haditha, $240 \mathrm{~km}$ north-west of Baghdad. A 20-year-old American soldier was killed by a roadside bomb explosion. In retaliation, U.S. Marines shot 24 Iraqi civilians including women and children [20]. The movie follows the story of the U.S. Marines, an Iraqi family, and the insurgents who made the roadside bomb [21]. In 2007, two years after the incident in Hadith, the film was produced with the participation of such actors as Elliot Ruiz, Yasmine Hanani, and Andrew McLaren. The project was spearheaded by world renowned British documentarian Nick Broomfield. The film was defined as a semidocumentary because it incorporates realism and many factual details, but it has a dramatized background and a fictitious storyline. This means that the plot indeed was based on real events, but it contains subjective interpretations. The film is located at the intersection of nonfiction and fiction.
Maintaining realism was a fundamental concept of this production, manifested in its cinematography, costumes, setting, and acting of the performers. Several former marines were involved in the project, such as Elliot Ruiz, a former marine corporal who fought in Iraq, who plays the role of Corporal Ramirez. Also the location is very similar to the Iraqi desert, because shots were taken in Jordan as both countries are similar in terrain. In the era of militainment, the semidocumentary movie has some news value, but its most important purpose is to attract attention. Every attempt to present reality faces aesthetic processes. For example the latest research shows that viewers derive pleasure from fast paced and quickly edited scenes [22]. This is connected with a theory about high-tech society that claims that the technological revolution and the development of mass media shape the perception of time in twenty-first century culture [23]. It leads to the situation where society expects to achieve more in a shorter time [23]. People live in a hurry and glorify a fast pace of life. Therefore, modern cinema follows this trend and concentrates on the speed and dynamism of a situation. Accordingly, in a war film, maximizing the feeling of satisfaction in a short time leads to the overrepresentation of aggression in relation to reality [24]. The film does not record real events but only uses the most important and interesting aspects of them. During the ninety minutes of Battle for Haditha there are an attack on a U.S. convoy, a civilian massacre in Haditha, and a bomb attack on the place occupied by the rebels. The quick accumulation of such scenes gives the film a fictional character and an emotional appeal.

War is inseparably linked with the image of death, which is a very sensitive issue. It is a difficult element in the perception of the modern viewer who desires seductive beauty and vitality. The image of death in war movies, such as Battle for Haditha, is manipulated by film aesthetics to show death as something that is good, heroic, and beautiful. Filmmakers turn tragedy into something positive that they can sell in the cinema. To portray the death of a positive character, they use slow motion effects which extend the celebration of the whole process, turning it into a fascinating ritual full of theatrical gestures. Death is deprived of its biological attributes, for example, the body is not decomposed.

Moreover, the death of young soldiers, as presented in Battle for Haditha, is used to create an icon of the war in Iraq, manufacturing the heroes and heroic actions that are needed in society. Battle for Haditha created three heroic myths. One is about young and brave soldiers who found themselves in severe conditions. The second describes enemies who are ruthless and threaten world peace. The last one presents American soldiers who never leave their friends without help even if they operate outside the law. What can be seen is that the film is made not to inform the viewer about the real situation. Instead it is more focused on evoking emotions. Presenting the attack on the soldiers produces sadness, grief and anger, and a desire for revenge. As a consequence, people start to believe that under these circumstances killing is justified. It is the way to correct this cruel reality. We can therefore consider militainment as a modern form of propaganda. 
On the contrary, the death of the enemy takes place at a faster than normal speed. This procedure can be observed in the episode concerning the revenge of the U.S. marines on Iraqi civilians. This sequence is a series of rapid and short shots. In that way, the deaths are illustrated so quickly that the viewer has no time to ask questions and dwell on what has been presented, and the deaths of many anonymous people make their pain become unnoticeable [9]. Dozens of unidentified characters are killed within ten minutes in Battle for Haditha. In the opening moment of the battle sequence, an American soldier kills five Iraqis who are wrongly blamed for detonating the bomb. The multiplication of the images of death largely trivializes it [25]. This type of representation of death reduces public opposition because of its transparency [26]. As it is said, "The death of one man is a tragedy. The death of millions is a statistic". Consequently, the death of supporting characters is neutralized and viewers are left with the illusion of its existence [25].

\section{CONCLUSIONS}

Formerly, there was a desire among cinema creators to capture an accurate representation of reality, but today they depart from this rule and decide to change war into a beautiful, fascinating, fictional spectacle. This project was based on the study of three selected films: Monthy Python's The Meaning of Life, The Atonement, and Battle for Hadditha. Each production offers the audience a new approach to the topic of war. The war film industry has proved to be sensitive to social and cultural changes, such as the fascination with violence, the development of the media, popular culture, and politics. Consequently, the militainment phenomenon makes watching war pleasurable instead of upsetting. In this context, ideological aspects of popular culture play a very important role of communicating certain attitudes and values which are socially desirable. The presentation of war in the context of entertainment is a way to meet society's expectations. Currently, presenting war in an attractive way contributes to the increase of its acceptance among audiences, which leads to a greater permission to wage war in reality.

\section{REFERENCES}

[1] R. Stahl. (2007). Militainment Inc. Militarism and Pop Culture Transcript. Media Education Foundation. [Online]. pp. 2. Available: http://www.mediaed.org/assets/products/135/transcript_135.pdf

[2] B. Sułkowski, Przemoc i Pornografia Śmierci Jako Przynęty Medialne, Łódź: Wydawnictwo Uniwersytety Łódzkiego, 2006, pp. 7-8

[3] W. Kuczok, To Piekielne Kino, Warszawa: Wydawnictwo W.A.B., 2006, pp. 38

[4] C. Barker, Cultural studies: theory and practice, London: Sage, 2005, pp. 78

[5] J. Grad and H. Mamzer, "Wprowadzenie," in Karnawalizacja. Tendencje Ludyczne w Kulturze Wspótczesnej, J. Grad, H. Mamzer, Eds. Poznań: UAM, 2004, pp. 7-9.

[6] J. Storey, Cultural Theory and Popular Culture: An Introduction, Harlow: Pearson Longman, 2009, pp. 12
[1] M. Brooke. Attack on a China Mission. [Online]. Available: http://www.screenonline.org.uk/film/id/520615/index.html.

[7] W. Lipoński, Dzieje Kultury Brytyjskiej, Warszawa: Wydawnictwo Naukowe PWN, 2003, pp. 720

[8] T. Kozłowski, "Popyt na seks i przemoc. Psychoewolucyjne uwarunkowania treści rozrywki, czyli dlaczego media lansują to, co lansują," in Erotyzm, Groza, Okrucieństwo-Dominanty Współczesnej Kultury, M. Kamińska, A. Horowski, Eds. Poznań: Wydawnictwo Naukowe Bogucki, 2008, pp. 227-236.

[9] J. Płażewski, Historia Filmu 1895-2000, Warszawa: Wydawnictwo Książka i Wiedza, 2001, pp. 204

[10] O. Katafiasz, "Komedia," in Stownik Wiedzy o Filmie, O. Katafiasz, J. Wojnicka, Eds. Bielsko-Biała:Wydawnictwo ParkEdukacja, 2005. pp. 386-390.

[11] K. Kucharski and J. Kristel, Seks w Kinie, Toruń: Torpress, 1990, pp. 45.

[12] M. Kornatowska, Eros i Film, Łódź:Krajowa Agencja Wydawnicza, 1986, pp. 12.

[13] W. Welsch, "Procesy estetyzacji. Zjawiska, rozróżnienia, perspektywy," in Sztuka i estetyzacja. Studia teoretyczne, M. Golka, K. Zamiara, Eds. Poznań: Wydawnictwo Fundacji Humaniora, 1999, pp $11-52$.

[14] M. Featherstone, "Postmodernizm i estetyzacja życia codziennego," in Postmodernizm Antologia Przykładów, R. Nycz, Ed. Kraków: Baran Suszczyński, 1997, pp. 304-326.

[15] K. Krzysztofek. (2010). Zmiksowana kultur. Magazyn Sztuki. [Online]. Avaialable:

http://www.dsw.muzeum.koszalin.pl/magazynsztuki/archiwum/lewa/p olityka_9.htm.

[16] G. Debord, Spoleczeństwo Spektaklu Oraz Rozważania o Spoleczeństwie Spektaklu, Warszawa: Państwowy Instytut Wydawniczy, 2006, pp. 33

[17] M. Nalikowski, "Estetyka wideoklipu,” Akcent, pp. 178, January 1991

[18] Ł. Waligórski. (2008). Oscary 2008. Analiza muzycznych nominacji [Online]. Available: http://muzykafilmowa.pl/artykuly/oscary2008.htm .

[19] PAP. (July 2011). USA/Ośmiu marines oskarżonych o udział w masakrze $\quad$ w Iraku. [Online]. Available: http://wiadomosci.gazeta.pl/Wiadomosci/1,80708,3809358.html

[20] R. Koehler. (September 2007). Battle of Haditha. Variety. [Online]. Available:http://www.variety.com/review/VE1117934755.html?categ oryid $=31 \& \mathrm{cs}=1$.

[21] A. Z. Janiszewska, "Od futurystycznych fantazji do estetyki znikania. Prędkość-film-media-śmierć," in Prędkość i Przyjemność. Kino i Telewizja w Dobie Symulacji Elektronicznej, A. Gwóźdź, Ed. Kielce: Szumacher, 1994. pp. 49-63.

[22] D. Mroczkowska, "Szybkość i pośpiech jako źródło przyjemności," in Rozważania Kulturoznawcze Kultura Przyjemności, J. Grad, H. Mamzer, Eds. Poznań:UAM. 2005, pp. 113-130.

[23] M. B. Gałkowska and I. U. Jaworska, Zabawa w Zabijanie, Lublin Gaudium, 2002, pp. 42.

[24] P. Zwierzchowski, Spektakl i Ideologia Szkice o Filmowych Wyobrażeniach Śmierci Heroicznej, Kraków: RABID, 2006, pp. 169.

[25] R. Syska, Film i Przemoc Sposoby Obrazowania Przemocy w Kinie, Kraków: RABID, 2003, pp. 51.

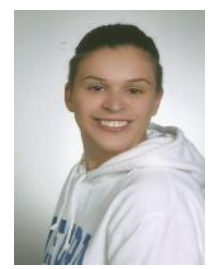

Olga Bogdańska was born in 1988, he is a Ph.D student at the Interdisciplinary Doctoral Program in the Humanities, University of Lodz. She received her M.A. in the field of International Relations from the Faculty of International and Political Studies (2012) and B.A. from the Department of Journalism and Social Communication (2013). She completed her internship at the International/European Federation of Journalists and participated in one-year studies at the Ghent University

in Belgium. During her studies she developed interest in cultural studies, literature and international mass media. 